\title{
Pollen Production in Relation to Ecological Class of Some Hydrophytes and Marsh Plants
}

\author{
Somnath Bhowmik ${ }^{*}$, Badal Kumar Datta \\ Plant Taxonomy and Biodiversity Laboratory, Department of Botany, Tripura University, Suryamaninagar, India. \\ Email: "sombhowmik@gmail.com
}

Received December $5^{\text {th }}, 2012$; revised January $5^{\text {th }}, 2013$; accepted January $12^{\text {th }}, 2013$

\begin{abstract}
The knowledge of quantitative production and method of dispersal give some idea about the frequency of presence of particular plant pollen grains in the atmosphere or hydrosphere. Pollen production in terms of number per anther along with the particular anther number per flower, anther length, pollen grain size, mode of anther dehiscence was determined for 51 angiospermous hydrophytes and marsh species occurring in Tripura, India. Pollen production is species specific. The level of pollen production directly related to the anther size and anther number per flower. However, no such correlation could be drawn between pollen production and size of pollen grains. Most of the hydrophytic taxa of the present investigation are anemophilous. The anemophilous taxa are characterized by high pollen production. However no correlation could be drawn from the present study between the high pollen production and mode of anther dehiscence as in all the studied taxa they show only one kind of anther dehiscence.
\end{abstract}

Keywords: Pollen Production; Hydrophytes; Ecological Class

\section{Introduction}

Studies on pollen, an organ which is considered to be less influenced by changing ecological condition, are relevant to various branches of Botany as well as to several other disciplines like Agriculture, Forestry, Medicine. Pollen productivity may be referred to as the number of pollen grains per produced per anther of a flower. The total pollen production of a particular plant is dependent upon the number of anthers per flower and the number of flowers per plant. The pollen production in an individual flower is fixed well before anthesis, and thus pollen presentation is a matter of doling out fixed quantities of floral reward. However, plants can alter the presentation schedule by sequential dehiscence of the anther or by a within anther time release mechanism [1]. A plant during its entire flowering period produces large amount of pollen grains most of which are not involved in fertilization. These large amount of pollen released may float in air or water and finally get deposited in earth's surface. The knowledge of quantitative production and method of dispersal give some idea about the frequency of presence of particular plant pollen grains in the atmosphere or hydrosphere [2]. Studies on pollen an organ which is considered to be less influenced by changing ecological condition, are relevant to various branches of Botany as well

${ }^{*}$ Corresponding author. as to several other disciplines like Agriculture, Forestry, Medicine. Pollen productivity may be referred to as the number of pollen grains per produced per anther of a flower. The total pollen production of a particular plant is dependent upon the number of anthers per flower and the number of flowers per plant. The pollen production in an individual flower is fixe well before anthesis, and thus pollen presentation is a matter of doling out fixed quantities of floral reward. However plants can alter the presentation schedule by sequential dehiscence of the anther or by anther time release mechanism [1]. A plant during its entire flowering period produces large amount of pollen grains most of which are not involved in fertilization. These large amount of pollen released may float in air or water and finally get deposited in earth's surface. The knowledge of quantitative production and method of dispersal give some idea about the frequency of presence of particular plant pollen grains in the atmosphere or hydrosphere [2]. A plant during its entire flowering period produces large amount of pollen grains most of which are not involved in fertilization. These large amount of pollen released may float in air or water and finally get deposited in earth's surface. Waterborne pollen and spores could come in contact with plants, animals and human beings, and affect them [3]. But the literature related to pollen production of aquatic and marshy land plants are scarce except a few $[4,5]$. The anthesis and Pollen release 
are important criteria for subsequent dispersal. Plants can alter the presentation schedule by sequential dehiscence of anthers or by a within- anther time release mechanism [1]. The ecology of anther dehiscence, pollen liberation and dispersal in Xanthium strumarium Linn was also reported [6]. The circadian patterns of pollen release in some anemophilous grasses of South India were also reported earlier [7]. The knowledge of anthesis and pollen production is essential to study of pollination, developing a functional model for forecasting pollen concentration and to understand more about the ecological background of pollen dispersal [8-10]. Several workers have, of course, studied the pollen production of terrestrial plants [11-16]. Other studies [17] provided an important contribution to the knowledge in the production of pollen in anemophilous trees but there is no record of pollen production for the hydrophytes and marsh plants and their relation with ecological class. In the present investigation we report the pollen production of 51 hydrophytes and marsh plants. An attempt has been made to correlate the data of pollen production with anther number, anther length, and pollen grain size, mode of anther dehiscence and with special stress on their ecological class.

\section{Materials and Methods}

The pollen production study was carried out following the standard methods $[18,19]$. The plants species for the present investigation were collected from different parts of Tripura. In determining pollen productivity we collected the mature and undehisced anthers from plants while they were in peak blooming season. We crushed one anther and dispersed it in 50 drops $50 \%$ glycerine. One drop of the mixture was put on a slide and covered with a $22 \mathrm{~mm} \times 22 \mathrm{~mm}$ cover glass. The number of pollen grains in this area was counted with an average of five drops for each species. This average was multiplied by 50 to get the number produced per anther. The pollen count was made for ten anthers randomly collected from different flowers of the aquatic plants. Five counting were made of each taxon, and the average number of pollen contained in an anther was derived. The size of the pollen grains (for radio symmetric ones the diameter in the polar view, and for bilateral ones the polar and equatorial axes) was measured in glycerine jelly [20] using standard ocular micrometer. For each taxon under study, pollen grain size was measured for 50 randomly chosen grains. Filament and anther length from mature stamens collected randomly from different flowers were measured through a $10 \times$ hand lens. The morphology and pollen grains size were studied. The hydrophytes and marsh plants so collected for the present investigation was grouped into 7 different "morpho-ecologic" classes [21].
These are (I) Floating Hydrophytes; (II) Suspended; (III) Submerged anchored hydrophytes; (IV) Floating leaved anchored hydrophytes; (V) Floating shoots anchored hydrophytes; (VI) Emergent anchored hydrophytes and (VII) Wetland helophytes.

\section{Results}

\subsection{Total Pollen Production}

From the pollen production figure obtained for 51 species which were distributed over twenty three families, it is evident that pollen production in terms of number per anther varies rather widely from family to family; genus to genus; species to species; even within the same genus (Table 1). The members of Nelumbonaceae, Nymphaeaceae, Convolvulaceae and Alismataceae rank the top most pollen producer among the studied taxa (Figure 1). The number of pollen grain per anther varied between 169 pollen grains in Persicaria orientale to 52,301 pollen grains in Nelumbo nucifera. Highest pollen production per anther was estimated in Nelumbo nucifera $(52,301$ pollen/anther) followed by Nymphaea micrantha $(45,350$ pollen/anther). Among the 51 aquatic and marsh land angiosperms 12 species with high pollen productivity, 20 with moderate and 19 species low pollen productivity is recorded in the present work. Nelumbo nucifera, Nymphaea micrantha, Nymphaea stellata, Nymphaea pubescens, Nymphaea rubra, Ipomoea fistulosa and Ipomoea aquatica show high pollen production. Floscopa scandens, Rumex maritimus, Centella asiatica, Rotala indica, Nymphoides cristatum, Hygrophila auriculata, Limnocharis flava, and Monochoria vaginalis showed moderate pollen production. While, Persicaria orientale, Polygonum

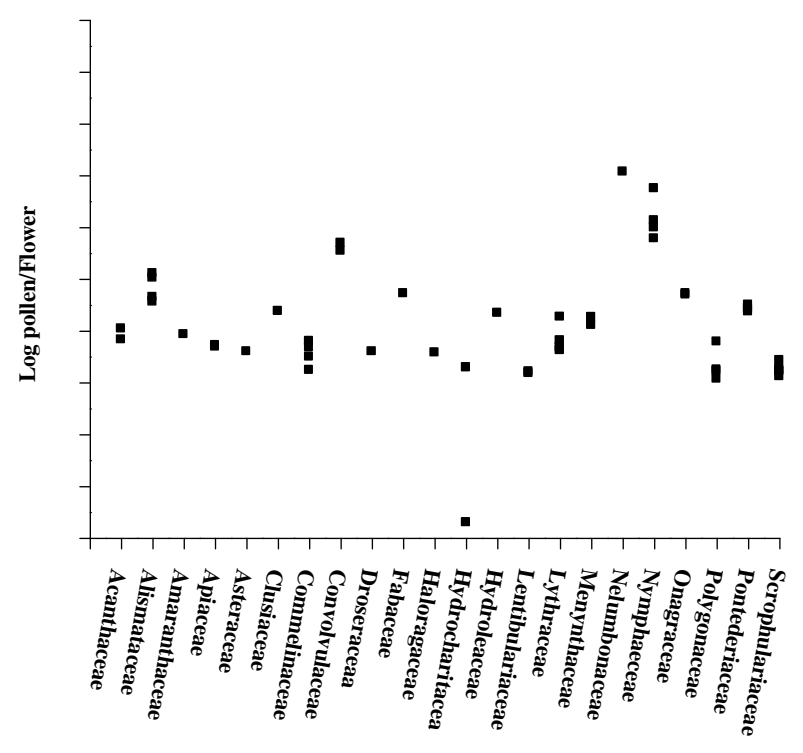

Figure 1. Pollen production of some hydrophytes and marsh plant families of Tripura, India. 
Table 1. Pollen production of some hydrophytes and marsh land plants from of Tripura.

\begin{tabular}{|c|c|c|c|c|c|c|c|c|c|c|c|c|}
\hline Sl.No & Botanical name & Habit & $\begin{array}{c}\text { Mode of } \\
\text { pollination }\end{array}$ & $\begin{array}{l}\text { Mode of } \\
\text { anther } \\
\text { dehiscence }\end{array}$ & $\begin{array}{l}\text { Ecological } \\
\text { class }\end{array}$ & $\begin{array}{l}\text { No of } \\
\text { anther } \\
\text { /flower }\end{array}$ & $\begin{array}{l}\text { Length } \\
\text { of } \\
\text { anther } \\
\text { (mm) }\end{array}$ & $\begin{array}{c}\text { Average } \\
\text { no } \\
\text { pollen/ } \\
\text { anther }\end{array}$ & $\begin{array}{l}\text { Pollen log } \\
\text { /anther }\end{array}$ & $\begin{array}{c}\text { Average } \\
\text { no of } \\
\text { pollen/ } \\
\text { flower }\end{array}$ & $\begin{array}{l}\text { Pollen size } \\
(\mu \mathrm{m})\end{array}$ & $\begin{array}{l}\text { Pollen size } \\
\text { class }\end{array}$ \\
\hline 1 & $\begin{array}{l}\text { Aeschynomene } \\
\text { indica Linnaeus }\end{array}$ & $\mathrm{S}$ & ENT & $\mathrm{L}$ & VI & 10 & $2.2-2.6$ & 5236 & 3.719 & 52360 & $\begin{array}{c}33.96 \times \\
25.36\end{array}$ & III \\
\hline 2 & $\begin{array}{c}\text { Alternanthera } \\
\text { philoxeroides } \\
\text { (Martius) Grisebach }\end{array}$ & $\mathrm{H}$ & ENT & $\mathrm{L}$ & VII & 5 & $1.5-1.7$ & 1698 & 3.230 & 8490 & $22 \times 10.22$ & II \\
\hline 3 & $\begin{array}{l}\text { Bacopa monnieri } \\
\text { (Linnaeus) Pennell }\end{array}$ & $\mathrm{H}$ & ENT & $\mathrm{L}$ & VII & 4 & $\begin{array}{l}1.85- \\
2.23\end{array}$ & 428 & 2.631 & 1712 & $\begin{array}{c}27.28 \times \\
22.23\end{array}$ & III \\
\hline 4 & $\begin{array}{l}\text { Centella asiatica } \\
\text { (Linnaeus) Urban }\end{array}$ & $\mathrm{H}$ & ENT & $\mathrm{L}$ & VII & 5 & $1.5-1.8$ & 1053 & 3.022 & 5265 & $\begin{array}{c}18.83 \times \\
15.43\end{array}$ & II \\
\hline 5 & $\begin{array}{c}\text { Commelina } \\
\text { benghalensis Linnaeus }\end{array}$ & $\mathrm{H}$ & ENT & $\mathrm{L}$ & VII & 6 & $1.5-1.7$ & 796 & 2.910 & 4776 & $\begin{array}{c}36.4 \times \\
19.39\end{array}$ & III \\
\hline 6 & $\begin{array}{l}\text { Cyanotis axillaris } \\
\text { (Linnaeus) Sweet }\end{array}$ & $\mathrm{H}$ & ENT & $\mathrm{L}$ & VII & 6 & $1.65-2.2$ & 1056 & 3.024 & 6336 & $\begin{array}{l}37.4 \times \\
20.46\end{array}$ & III \\
\hline 7 & $\begin{array}{l}\text { Cyanotis cristata } \\
\text { (Linnaeus) D.Don . }\end{array}$ & $\mathrm{H}$ & ENT & $\mathrm{L}$ & VII & 6 & $1.4-1.5$ & 529 & 2.723 & 3174 & $\begin{array}{l}35.6 \times \\
20.22\end{array}$ & III \\
\hline 8 & $\begin{array}{l}\text { Dopatrium junceum } \\
\text { (Roxburgh) F.Hamilton } \\
\text { ex Bentham }\end{array}$ & $\mathrm{H}$ & ENT & $\mathrm{L}$ & VI & 2 & $0.8-1.0$ & 921 & 2.964 & 1842 & $\begin{array}{l}35.4 \times \\
21.38\end{array}$ & III \\
\hline 9 & Drosera burmnni Vahl & $\mathrm{H}$ & ENT & $\mathrm{L}$ & VII & 5 & $1.0-1.25$ & 803 & 2.905 & 4015 & $\begin{array}{l}46.2 \times \\
25.08\end{array}$ & III \\
\hline 10 & $\begin{array}{l}\text { Eichornia crassipes } \\
\text { (Martius) Solms }\end{array}$ & $\mathrm{H}$ & ANE & $\mathrm{L}$ & I & 6 & $3.1-4.0$ & 3915 & 3.593 & 23490 & $\begin{array}{c}44.22 \times \\
25.52\end{array}$ & III \\
\hline 11 & $\begin{array}{l}\text { Enhydra fluctuans } \\
\text { Loureiro }\end{array}$ & $\mathrm{H}$ & ENT & $\mathrm{L}$ & VI & 5 & $\begin{array}{l}0.48- \\
0.55\end{array}$ & 788 & 2.896 & 3940 & $25.3 \times 23.5$ & III \\
\hline 12 & $\begin{array}{c}\text { Floscopa scandens } \\
\text { Loureiro }\end{array}$ & $\mathrm{H}$ & ENT & $\mathrm{L}$ & VII & 6 & $2.5-2.7$ & 1025 & 3.011 & 6150 & $\begin{array}{c}36.41 \times \\
20.11\end{array}$ & III \\
\hline 13 & $\begin{array}{c}\text { Hydrilla verticillata } \\
\text { Richard }\end{array}$ & $\mathrm{H}$ & HYD & $\mathrm{L}$ & III & 3 & $0.4-0.5$ & 652 & 2.814 & 1956 & $\begin{array}{c}22.00 \times \\
18.92\end{array}$ & II \\
\hline 14 & $\begin{array}{c}\text { Hydrocotyl } \\
\text { sibthorpioides Lamarck }\end{array}$ & $\mathrm{H}$ & ENT & $\mathrm{L}$ & VII & 5 & $1.0-1.25$ & 973 & 2.988 & 4865 & $\begin{array}{c}18.74 \times \\
17.82\end{array}$ & II \\
\hline 15 & $\begin{array}{l}\text { Hydrolea zeylanica } \\
\text { (Linnaeus) Vahl }\end{array}$ & $\mathrm{H}$ & ENT & $\mathrm{L}$ & VII & 5 & $\begin{array}{l}2.01- \\
2.03\end{array}$ & 4410 & 3.645 & 22050 & $\begin{array}{c}23.84 \times \\
22.22\end{array}$ & II \\
\hline 16 & $\begin{array}{l}\text { Hygrophila auriculata } \\
\text { ( Schumacher) Heine }\end{array}$ & $\mathrm{H}$ & ANE & $\mathrm{L}$ & VII & 4 & $2.2-2.3$ & 2753 & 3.434 & 11012 & $\begin{array}{c}36.96 \times \\
29.48\end{array}$ & III \\
\hline 17 & $\begin{array}{l}\text { Hygrophila salicifolia } \\
\text { (Vahl) Nees }\end{array}$ & $\mathrm{H}$ & ANE & $\mathrm{L}$ & VII & 4 & $1.7-2.0$ & 1698 & 3.230 & 6792 & $\begin{array}{c}31.73 \times \\
31.27\end{array}$ & III \\
\hline 18 & $\begin{array}{l}\text { Hypericum japonicum } \\
\text { Thunb. ex Murray }\end{array}$ & $\mathrm{H}$ & ENT & $\mathrm{L}$ & VII & 21 & $1.0-1.1$ & 1154 & 3.062 & 24234 & $\begin{array}{c}17.21 \times \\
17.86\end{array}$ & II \\
\hline 19 & $\begin{array}{l}\text { Ipomoea aquatica } \\
\text { Froster }\end{array}$ & $\mathrm{H}$ & ANE & $\mathrm{L}$ & V & 5 & $5.2-5.8$ & 31520 & 4.498 & 350725 & $\begin{array}{c}73.92 \times \\
73.92\end{array}$ & IV \\
\hline 20 & $\begin{array}{l}\text { Ipomoea fistulosa } \\
\text { Martius ex Choisy }\end{array}$ & S & ANE & $\mathrm{L}$ & VII & 5 & $6.0-6.5$ & 32650 & 4.514 & 487425 & $\begin{array}{l}75.68 \times \\
75.68\end{array}$ & IV \\
\hline 21 & $\begin{array}{c}\text { Limnocharis flava } \\
\text { (Linnaeus) Buchanon } \\
\text { Hamityon }\end{array}$ & $\mathrm{H}$ & ANE & $\mathrm{L}$ & VI & 23 & $2.0-2.1$ & 4520 & 3.655 & 103960 & $\begin{array}{c}26.87 \times \\
20.69\end{array}$ & III \\
\hline 22 & $\begin{array}{l}\text { Limnophila sessiliflora } \\
\text { (Vahl) Blume }\end{array}$ & $\mathrm{H}$ & ENT & $\mathrm{L}$ & VI & 4 & $1.0-1.1$ & 418 & 2.621 & 1672 & $\begin{array}{c}22.26 \times \\
17.34\end{array}$ & II \\
\hline 23 & $\begin{array}{l}\text { Lindernia anagallis } \\
\text { (N. L. Burman) Pennell }\end{array}$ & $\mathrm{H}$ & ENT & $\mathrm{L}$ & VII & 4 & $1.0-1.2$ & 668 & 2.824 & 2672 & $\begin{array}{c}21.12 \times \\
19.80\end{array}$ & II \\
\hline 24 & $\begin{array}{l}\text { Lindernia ciliata } \\
\text { (Colsmann) Pennell }\end{array}$ & $\mathrm{H}$ & ENT & $\mathrm{L}$ & VII & 2 & $1.0-1.3$ & 657 & 2.817 & 1314 & $\begin{array}{c}18.26 \times \\
20.02\end{array}$ & II \\
\hline 25 & $\begin{array}{l}\text { Ludwigia adscendens } \\
\text { (Linnaeus) Hara }\end{array}$ & $\mathrm{H}$ & ENT & $\mathrm{L}$ & V & 10 & $\begin{array}{l}1.02- \\
1.52\end{array}$ & 5069 & 3.705 & 50690 & $\begin{array}{l}57.2 \times \\
69.52\end{array}$ & IV \\
\hline
\end{tabular}




\section{Continued}

\begin{tabular}{|c|c|c|c|c|c|c|c|c|c|c|c|c|}
\hline 26 & $\begin{array}{l}\text { Ludwigia octovalvis } \\
\text { subsp. sessiliflora } \\
\text { (Micheli) P. H. Raven ) }\end{array}$ & $\mathrm{H}$ & ENT & $\mathrm{L}$ & VII & 8 & $1.2-1.3$ & 2412 & 3.382 & 52241 & $\begin{array}{c}55.25 \times \\
52.78\end{array}$ & IV \\
\hline 27 & $\begin{array}{l}\text { Monochoria hastata } \\
\text { (Linnaeus) Solm }\end{array}$ & $\mathrm{H}$ & ANE & $\mathrm{L}$ & VII & 6 & $3.0-5.1$ & 5316 & 3.725 & 31896 & $\begin{array}{c}43.34 \times \\
20.24\end{array}$ & III \\
\hline 28 & $\begin{array}{l}\text { Monochoria vaginalis } \\
\text { ((Burm.f.) Presler }\end{array}$ & $\mathrm{H}$ & ANE & $\mathrm{L}$ & VI & 6 & $3.0-4.75$ & 4529 & 3.656 & 27174 & $\begin{array}{c}43.34 \times \\
25.52\end{array}$ & III \\
\hline 29 & $\begin{array}{l}\text { Murdannia nudiflora } \\
\text { (Linnaeus) Brenan }\end{array}$ & $\mathrm{H}$ & ENT & $\mathrm{L}$ & VII & 2 & $0.5-0.6$ & 864 & 2.936 & 1728 & $\begin{array}{l}37.9 \times \\
20.58\end{array}$ & III \\
\hline 30 & $\begin{array}{c}\text { Myriophyllum } \\
\text { tuberculatum Roxburgh }\end{array}$ & $\mathrm{H}$ & ENT & $\mathrm{L}$ & V & 4 & $0.5-0.7$ & 945 & 2.975 & 3780 & $\begin{array}{l}19.8 \times \\
21.12\end{array}$ & III \\
\hline 31 & $\begin{array}{l}\text { Nelumbo nucifera } \\
\text { Gaertner }\end{array}$ & $\mathrm{H}$ & ENT & $\mathrm{L}$ & IV & 224 & $14-15.2$ & 52301 & 4.718 & 11715424 & $\begin{array}{c}57.86 \times \\
49.72\end{array}$ & IV \\
\hline 32 & $\begin{array}{l}\text { Nymphaea micrantha } \\
\text { Guillemin and Perrottet }\end{array}$ & $\mathrm{H}$ & ENT & $\mathrm{L}$ & IV & 123 & $\begin{array}{c}12.00- \\
15.6\end{array}$ & 45350 & 4.657 & 5578050 & $\begin{array}{c}21.12 \times \\
33.38\end{array}$ & III \\
\hline 33 & $\begin{array}{l}\text { Nymphaea pubescens } \\
\text { Willdenow }\end{array}$ & $\mathrm{H}$ & ENT & $\mathrm{L}$ & IV & 30 & $\begin{array}{c}10.5- \\
12.7\end{array}$ & 42309 & 4.626 & 606780 & $\begin{array}{c}22.47 \times \\
34.58\end{array}$ & III \\
\hline 34 & $\begin{array}{l}\text { Nymphaea rubra } \\
\text { Roxburgh ex Andrews }\end{array}$ & $\mathrm{H}$ & ENT & $\mathrm{L}$ & IV & 48 & $9.0-11.5$ & 40217 & 4.604 & 1333920 & $\begin{array}{c}16.83 \times \\
29.7\end{array}$ & III \\
\hline 35 & $\begin{array}{l}\text { Nymphaea stellata } \\
\text { F. Mueller }\end{array}$ & $\mathrm{H}$ & ENT & $\mathrm{L}$ & IV & 36 & $\begin{array}{l}10.5- \\
12.5\end{array}$ & 43874 & 4.642 & 966240 & $\begin{array}{c}28.07 \times \\
37.61\end{array}$ & III \\
\hline 36 & $\begin{array}{l}\text { Nymphoides cristatum } \\
\text { (Roxburgh) O.Kuntze }\end{array}$ & $\mathrm{H}$ & ENT & $\mathrm{L}$ & IV & 5 & $1.5-1.7$ & 2583 & 3.412 & 12940 & $\begin{array}{c}25.48 \times \\
35.72\end{array}$ & III \\
\hline 37 & $\begin{array}{l}\text { Nymphoides indica } \\
\text { (Linnaeus) Kuntze }\end{array}$ & $\mathrm{H}$ & ENT & $\mathrm{L}$ & IV & 5 & $1.9-2.1$ & 3678 & 3.566 & 18390 & $\begin{array}{c}35.72 \times \\
32.87\end{array}$ & III \\
\hline 38 & $\begin{array}{l}\text { Ottelia alismoides } \\
\text { (Linnaeus) Persoon }\end{array}$ & $\mathrm{H}$ & ANE & $\mathrm{L}$ & III & 12 & $6.2-7.0$ & 3754 & 3.575 & 45048 & $25.3 \times 23.5$ & III \\
\hline 39 & $\begin{array}{l}\text { Persicaria hydropiper } \\
\text { (Linnaeus) Spach }\end{array}$ & $\mathrm{H}$ & ENT & $\mathrm{L}$ & VI & 7 & $1.0-1.2$ & 254 & 2.405 & 1778 & $\begin{array}{c}38.72 \times \\
33.56\end{array}$ & III \\
\hline 40 & $\begin{array}{l}\text { Persicaria orientalis } \\
\text { (Linnaeus) Assenov }\end{array}$ & $\mathrm{H}$ & ENT & $\mathrm{L}$ & VI & 7 & $1.1-1.2$ & 169 & 2.228 & 1183 & $\begin{array}{c}37.53 \times \\
35.55\end{array}$ & III \\
\hline 41 & $\begin{array}{l}\text { Polygonum strigosum } \\
\text { R. Brown . }\end{array}$ & $\mathrm{H}$ & ENT & $\mathrm{L}$ & VII & 7 & $1.1-1.2$ & 236 & 2.373 & 1652 & $\begin{array}{c}37.62 \times \\
34.44\end{array}$ & III \\
\hline 42 & $\begin{array}{l}\text { Rotala densiflora } \\
\text { (Roth ex Roemer et } \\
\text { Schultes) Koehne }\end{array}$ & $\mathrm{H}$ & ENT & $\mathrm{L}$ & VII & 4 & $1.1-1.2$ & 1206 & 3.081 & 4824 & $\begin{array}{c}17.16 \times \\
14.96\end{array}$ & II \\
\hline 43 & $\begin{array}{c}\text { Rotala indica } \\
\text { (Willdenow) Koehne }\end{array}$ & $\mathrm{H}$ & ENT & $\mathrm{L}$ & VII & 4 & $1.0-1.1$ & 1630 & 3.212 & 6520 & $\begin{array}{c}17.11 \times \\
13.96\end{array}$ & II \\
\hline 44 & $\begin{array}{l}\text { Rotala rotundifolia } \\
\text { (Buch.-Ham. ex } \\
\text { Roxburgh) Koehne }\end{array}$ & $\mathrm{H}$ & ENT & $\mathrm{L}$ & VII & 4 & $0.9-1.1$ & 1054 & 3.023 & 4216 & $\begin{array}{c}17.10 \times \\
14.52\end{array}$ & II \\
\hline 45 & $\begin{array}{l}\text { Rumex maritimus } \\
\text { Linnaeus }\end{array}$ & $\mathrm{H}$ & ENT & $\mathrm{L}$ & VII & 6 & $1.0-1.1$ & 1026 & 3.011 & 6156 & $\begin{array}{c}24.59 \times \\
24.59\end{array}$ & II \\
\hline 46 & $\begin{array}{l}\text { Sagittria guayanensis } \\
\text { Linnaeus }\end{array}$ & $\mathrm{H}$ & ANE & $\mathrm{L}$ & VII & 7 & $2.0-2.5$ & 5203 & 3.716 & 36421 & $\begin{array}{c}74.92 \times \\
71.26\end{array}$ & III \\
\hline 47 & $\begin{array}{l}\text { Sagittria sagitifolia } \\
\text { Linnaeus . }\end{array}$ & $\mathrm{H}$ & ANE & $\mathrm{L}$ & I & 24 & $2.7-2.8$ & 5338 & 3.727 & 128112 & $\begin{array}{c}72.92 \times \\
70.26\end{array}$ & III \\
\hline 48 & $\begin{array}{l}\text { Trapa natuns var } \\
\text { bispinosa } \\
\text { (Roxburgh) Makino }\end{array}$ & $\mathrm{H}$ & ENT & $\mathrm{L}$ & I & 5 & $1.1-1.2$ & 3690 & 3.567 & 18450 & $\begin{array}{c}52.36 \times \\
58.52\end{array}$ & IV \\
\hline 49 & $\begin{array}{l}\text { Utricularia aurea } \\
\text { Loureiro }\end{array}$ & $\mathrm{H}$ & ENT & $\mathrm{L}$ & II & 2 & $0.5-0.6$ & 756 & 2.879 & 1512 & $\begin{array}{c}45.59 \times \\
47.76\end{array}$ & III \\
\hline 50 & $\begin{array}{c}\text { Utricularia gibba } \\
\text { subsp exoleta Roxburgh }\end{array}$ & $\mathrm{H}$ & ENT & $\mathrm{L}$ & II & 2 & $0.6-0.7$ & 819 & 2.913 & 1638 & $\begin{array}{c}30.45 \times \\
35.64\end{array}$ & III \\
\hline 51 & $\begin{array}{l}\text { Vallisneria spiralis } \\
\text { Linnaeus }\end{array}$ & $\mathrm{H}$ & HYD & $\mathrm{L}$ & II & 1 & $0.1-0.15$ & 620 & 2.792 & 620 & $\begin{array}{c}17.85 \times \\
15.33\end{array}$ & II \\
\hline
\end{tabular}

(Pollen production class: High pollen production: $>5000$ pollen per anther; Moderate pollen production: $1000-5000>$ pollen per anther; Low pollen production: $\leq 1000$ pollen per anther. Pollen size class: $\leq 10 \mu \mathrm{m}-\mathrm{I} ; 10$ - $25 \mu \mathrm{m}-\mathrm{II} ; 25$ - $50 \mu \mathrm{m}-\mathrm{III} ; 50$ - $100 \mu \mathrm{m}-\mathrm{IV} ; 100$ - $200 \mu \mathrm{m}-\mathrm{V} ; \geq 200 \mu \mathrm{m}-\mathrm{V}$. Anther length class: Small anther: $\leq 1 \mathrm{~mm}$; Medium sized anther: $1-5 . \mathrm{mm}$; Large sized anther : $\geq 5 \mathrm{~mm}$ ) 
strigosum, Persicaria hydropiper, Limnophila sessiliflora, Bacopa monnieri, Vallisneria spiralis, Dopatrium junceum, Myriophyllum tuberculatum showed low pollen production.

\subsection{Correlation between Anther Number per Flower and Total Pollen Production}

The total pollen production is directly correlated to the number of anther per flower. There is significant $(\mathrm{p}<$ 0.0001 ) positive and linear correlation between the number of pollen grains and of anther per flower (Figure 2). By calculating the linear regression we find logy = $318721.66+50625.95 x$ (y being the dependent variable: the number of grains per flower; and $\mathrm{x}$ the dependent variable: the number of the anther). Nelumbo nucifera, Nymphaea micrantha, Nymphaea stellata, Nymphaea pubescens, Nymphaea rubra rank the top most pollen producers with their high anther number

\subsection{Correlation between Anther Length and Pollen Production}

The total pollen production is directly correlated to the anther length. In other words species possessing large anthers have higher rate of pollen production. A positive significant correlation has been found between the anther length and the number of pollen grains produced per anther $(r=0.95, p=0.0001$; Figure 3) using a total of 255 data ( 5 anthers per plant in a total of 51 species). Ne-

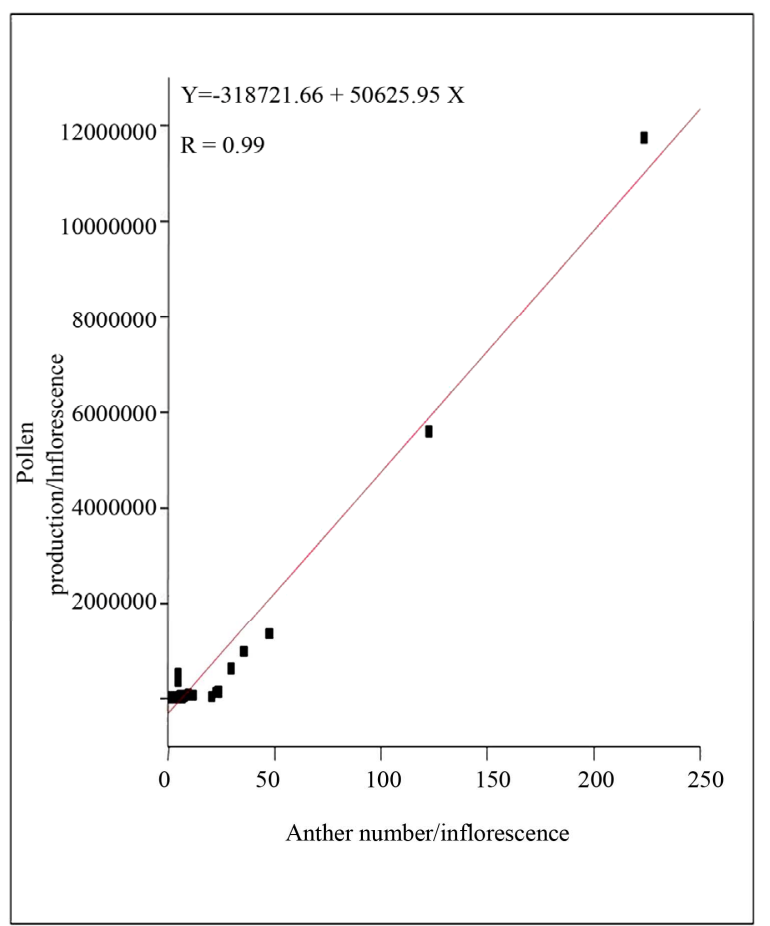

Figure 2. Correlations between anther number and pollen production.

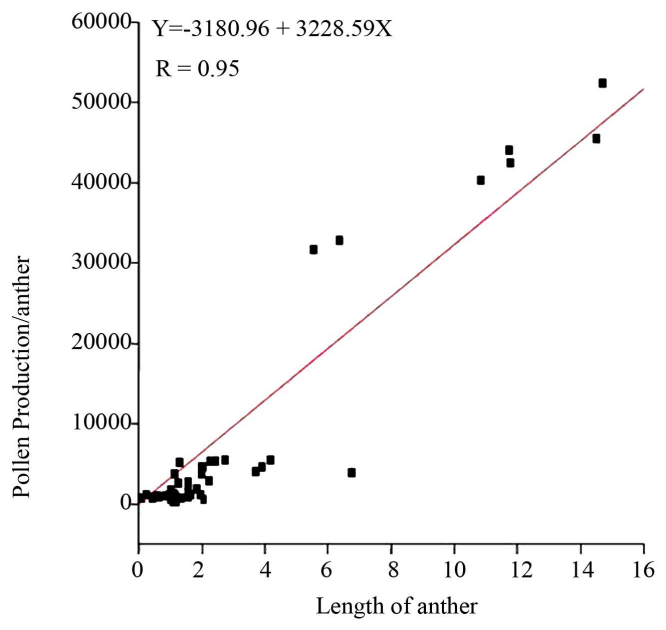

Figure 3. Correlation between anther length and pollen production.

lumbo nucifera, Nymphaea micrantha, Nymphaea stellata, Nymphaea pubescens, Nymphaea rubra, Ipomoea fistulosa where high pollen productivity could be correlated to their large anther size. Among studied taxa Nelumbo nucifera with long anther length had the highest pollen productivity $(52,301$ pollen/anther). The 4 studied species of Nymphaea show a relationship in terms of pollen production and their anther length. Nymphaea micrantha with long anther size show high degree of pollen productivity $(45,350$ pollen/anther) as comparison to other species of Nymphaea. Myriophyllum tuberculatum, Murdannia nudiflora, Utricularia gibba subsp exoleta, Utricularia aurea, Hydrilla verticillata and Vallisneria spiralis show low pollen productivity with small anther size. By calculating the linear regression we find $\log y=3180.96+3228.59 x$ (y being the dependent variable: the number of grains per anther; and $\mathrm{x}$ the dependent variable: the length of the anther).

\subsection{Pollen Production and Pollen Size}

Data on pollen size - polar diameter $(\mathrm{P})$ and equatorial diameter (E) were collected from the pollen grains. Equatorial diameter (E) was taken to assess the size of the pollen grains. In the present study most of the studied taxa were found to posses medium sized pollen grains $(25-49 \mu \mathrm{m})$. Pollen production is not only dependent on the anther size but also on the pollen grain size. However in the present study no direct correlation was found in relation to pollen production and pollen size. Though in, Alternanthera philoxeroides, Centella asiatica, Hydrolea zeylanica, Hypericum japonicum, Rotala densiflora, Rotala indica, Rotala rotundifolia and in Rumex maritimus where medium anther length with small sized pollen grains could be correlated with moderate pollen production. 


\subsection{Relation between Pollen Production and Ecological Class with Pollination Mechanism}

The 51 studied taxa distributed over 7 ecological classes. From the data (Figure 4) it is clear that the plant belongs to Floating Leaves Anchored Hydrophytes (Class IV) produce copious amount of pollen per flower followed by those belonging to the Floating Shoot Anchored Hydrophyte (Class V). The Submerged herbs (Class II) produce the least amount of pollen per flower. In the present investigation most of the aquatic and marshy plants are anemophilous rarely they show hydrophilous mode of pollination.

\subsection{Pollen Production and Mode of Pollination}

Of the 51 species studied, 38 taxa show entomophilies (ENT), 11 taxa are anemophilous (ANE) and 2 taxa show hydrophilous (HYD) (Figure 5). The anemophilous specie of the present investigation produces copious amount of pollen/flower than those of entemophilous species. The flower of the most aquatic plants angiosperms must be elevated above the water surface in order for pollination to occur. Aquatic plants are taxonomically diverse and they are pollinated by a large number of aerial and aquatic mechanisms. Pollination in most aquatic plants

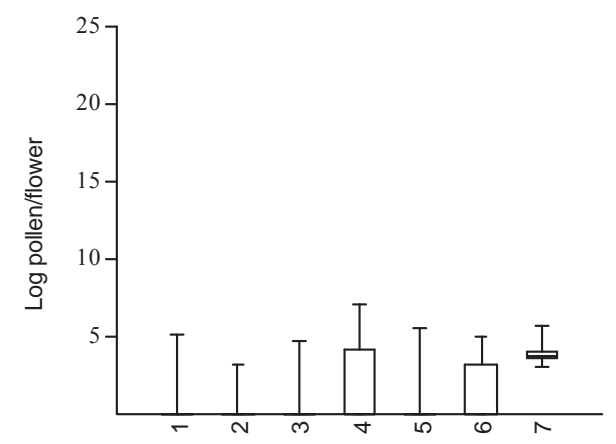

Figure 4. Relation between ecological class and pollen production of hydrophytes and marsh plants.

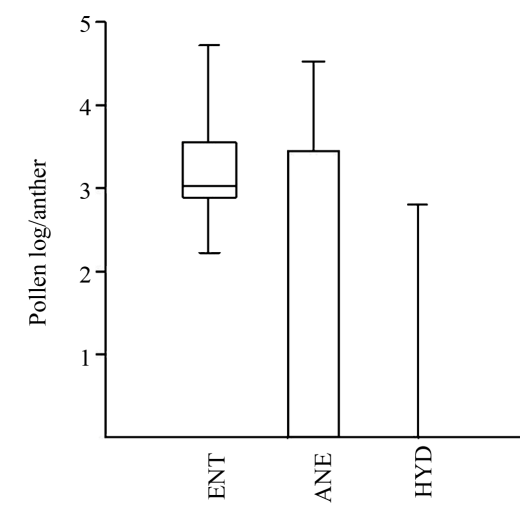

Figure 5. Relation between pollen production and mode of pollination. including submerged ones, occur in the air either through the biotic pollination or anemophily.

\subsection{Pollen Production and Anther Dehiscence}

Of the 51 species studied, in all species the anther dehiscing through longitudinal slits. There seems to be no correlation between higher rate of pollen production and a particular mode of anther opening.

\section{Discussions}

Variations in pollen production as are recorded now were also reported by other workers [22-25]. A comparison of data of pollen production of investigated plants with their anther length appeared to be directly related to pollen production. The correlation between the size of the anther and the quantity of pollen grains they contain has already been demonstrated by other authors $[13,25]$. There is a positive association between anther size and pollen produced per anther [26,27]. There was a proportionate increase in the degree of pollen production with the increase in the length of stamen in Cassia tora and Arachis hypogea of Leguminosae [28]. The production of pollen of the Poaceae family varies greatly and found between 800 (Cynodon dactylon) and 13,000 (Secale cereale) grains per anther, and suggest that the total production of pollen depends directly on the size and length of the anther, calculating a value of 700 - 1200 pollen grains per millimetre of anther length [23]. In Oryza sativa polyploidy causes the number of pollen grains and the size of the anthers to increase, while the ratio between the two decreases [29]. In the present study no correlation between pollen grain size and anther dehiscence with pollen production is established. The grain size seems to be of no importance in Poaceae, Cyperaceae and Amaranthaceae-Chenopodiaceae [13,30].

To represent the phenetic relationships within the twenty three clades of vascular plant families from dicotyledons and monocotyledons, a dendrogram based on pollen production and anther length of selected taxa from respective plant families was constructed which can be thought as a model for the phenetic relationships among the clades (Figure 6). The information about this phenetic model is completely contained in the co-phenetic similarities of the clades obtained from the dendrogram. There are two major phenetic hypotheses for the similarities in their palynological characters; these two clades separates two major families viz. Nelumbonaceae and Nymphaeaceae form remaining eighteen families. Furthermore, two clades categorize two families amusingly to form dicotyledons and monocotyledons together viz. Convolvulaceae and Alismataceae. Foremost families from monocotyledons (Commelinaceae, Pontederiaceae) to dicotyledons (Polygonaceae, Droseraceae, etc.) have 
gather to form a large clade and it is quite considerable. In case of phenon lines, apart from Asteraceae, Droseraceae and Halorgaceae all families are below 90\% similar to each other. Dendrogram (Figure 6) explains possible clades with respect to their similarities. Convolvulaceae and Alismataceae are forms a distinct clades however, they are quite diverse morphologically. Families like Commelinaceae and Pontederiaceae are belonging to order Commelinales but in present study these two families positioned in unusual manner.

Among the studied plants all the species anther dehisces through longitudinal slits. So no direct correlation can draw from the present study. It was reported that there is no correlation between the rates of pollen production and a particular mode of anther opening [13]. There existed a correlation between pollen production and habit of the plant - an increase in pollen production from herb to shrubs and to trees [2]. In the present investtigation, no such correlation can be drawn between pollen production and the habit of the plant because mostly all the species belong to same habitat group. It has been observed that the rooted hydrophytes with floating leaves produced highest amount of pollen grains than the submerged, marginal and free floating hydrophytes [31].Our investigation also supports these previous observations. Due to self-pollination (Entomophilly) pollen grains production is high in the genus Nymphaea [32]. The pollen production is a characteristic of all plants, and is by definition, an integral part of the pollination process [32].The flower of the most aquatic plants angiosperms must be elevated above the water surface in order for pollination

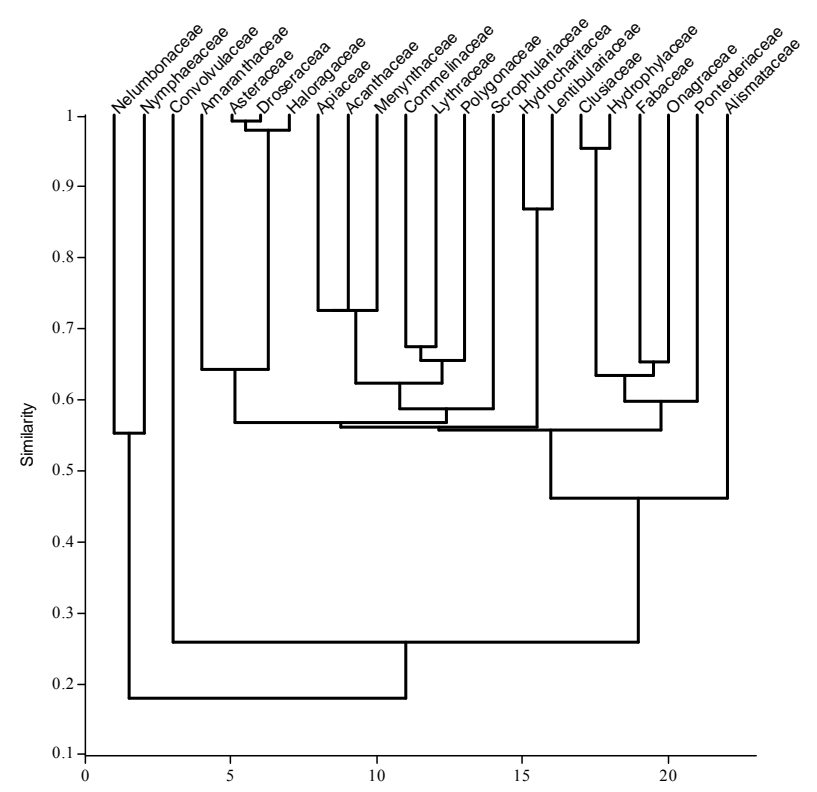

Figure 6. Dendogram showing the phonetic relationship on the basis of pollen production, anther length and anther number. to occur. Hydrophytes are taxonomically diverse and they are pollinated by a large number of aerial and aquatic mechanisms [33,34]. Pollination in most aquatic plants including submerged ones, occur in the air either through the biotic pollination or anemophily [35]. The high proportion of anemophily mode of pollination in hydrophytes plants is due to systematic affinity rather than functional constraints [36]. Conversely hydrophily is more limited, and is categorized by the location of pollen transport. The association between Hydrophytes and anemophily has long been recognized and was believed to be an adaptive characteristic [37]. The association between anemophily and hydrophytes thus appear to be due systematic affinity, rather than selective pressure of the aquatic environment. Hydrophily, or under water pollination, is relatively uncommon in angiosperms. The hydrophilous mode of pollination and is largely restricted to the monocotyledons. The study of pollen production helped to locate the differences in the biological potential of individual flower in an inflorescence [38]. It is also differed in individual anther of a flower [12] in diploids and tetraploids [29] in anther, flower and plant with reference to dispersal [19], in anther and flower [39], in anther, flower and whole plant $[40,41]$, and in terms of number per anther along with the anther length, filament length, pollen grains size and mode of anther dehiscence [13]. However it is evident that pollen production per flower in a taxon not only depends on the size of anther or the size of the pollen grains but it is also controlled by many other factors such as periodicity, response to light, nutrient availability etc. [38]. Temperature and season also seems to effect pollen production [42]. The effect of temperature is really on the development of the stamens into organs with normal functional theca. The amount of pollen produced by an individual plant might be genetically fixed [24]. Even varieties among cultivated species differ from one another as their pollen production [43]. The amount of pollen in the atmosphere depends not only on pollen production but also on the duration of the flowering season and on environmental factors [44]. It cannot, therefore, be deduced solely from pollen production by the inflorescence. The most important meteorological factors are moisture, minimum temperature, and sunshine hours [45]. After the study it has been concluded that pollen production in aquatic hydrophytes were not related directly with the size of flower and the anther or size of pollen grains but it also controlled by other factors such as periodicity, response to light and nutrient availability [46]. The pollen production may affect the percentage of fruit set in plants [45]. Hence it is of great importance in plant improvement programs. The production of large amount of pollen by a plant during its flowering period may result in the deposition of its pollen grains in a particular area and could be used as an index 
of the vegetation pattern of that area [2].

\section{Acknowledgements}

The first author is thankful Tripura University, India, for providing RET Fellowship in order to carry out the research work. The first author also greets his warm regards to Mr. Mayur Nandikar, SRF, Shivaji University, Kolhapur and Mr. Joydeb Majumder, JRF, Tripura University for their continuous assistant during statistical analysis.

\section{REFERENCES}

[1] S. L. Buchmann, C. E. Jones and L. J. Colin, "Vibratile Pollination of Solanum douglassi and S. xanti (Solanaceae) in Southern California," Wasmann Journal of Biology, Vol. 35, 1977, pp. 1-25.

[2] A. K. Mondal and S. Mandal, "Pollen Production in Some Terrestrial Angiosperms," Current Science, Vol. 74, No. 10, 1998, pp. 906-910.

[3] P. K. Dan, C. H. Rahaman and S. Mandal, "Prevalence of Airborne Pollen and Spores in the Aquatic Environments of Birbhum District, West Bengal, India," Proceedings of 4th International Conference on Aerobiology, Stockholm, 27-31 August 1990, pp. 105-111

[4] P. K. Dan and S. Mandal, "Pollen and Fungal Spores in an Aquatic Environment, West Bengal Preliminary Report," Indian Journal of Aerobiology, Vol. 15, 1992, pp. 193-196.

[5] M. J. Diez, S. Talavera and P. Garcia-Murillo, "Contribution to the Palynology of Hydrophytic Non-Entomophilous Angiosperms I. Studies with LM and SEM," Candoellea, Vol. 43, 1988, pp. 147-158.

[6] C. S. Reddi, E. U. B. Reddi, A. Janaki Bai, K. V. R. Raju and M. S. Reddi, "The Ecology of Anther Dehiscence, Pollen Liberation and Dispersal in Xanthium strumarium Linn," Indian Journal of Ecology, Vol. 7, 1980, pp. 171181

[7] C. S. Reddi, N. S. Hoddi and A. J. Bai, "Circadian Patterns of Pollen Release in Some Species of Poaceae," Review of Palaeobotany and Palynology, Vol. 54, No. 1-2, 1988, pp. 11-42. doi:10.1016/0034-6667(88)90003-6

[8] R. L. Davidson, “A Note on Anthesis on Some Common Grasses near Jonesburg and the Relation of Anthesis to Collection of Pollen for Medical Purpose," South African Journal of Botany, Vol. 7, 1941, pp. 145-152.

A. Bhattacharya and B. K. Datta, "Anthesis and Pollen Release of Some Plants of West Bengal, India," Grana, Vol. 31, No. 1, 1992, pp. 67-71.

doi: $10.1080 / 00173139209427828$

[9] M. S. U. Islam, R. Abid and M. Qaiser, "Anther Types of the Dicots within Flora of Karachi, Pakistan," Pakistan Journal of Botany, Vol. 40. No. 1, 2008, pp. 33-41.

[10] R. K. Sharma and P. K. K. Nair, "A Study of Pollen Production in Brassica L.," Palynological Bulletin, Vol. 6, No. 2, 1970, pp. 62-66.

[11] R. S. Vaish, "Pollen Production in Lablab niger," Journal of Palynology, Vol. 9, 1973, pp. 83-86.

[12] C. S. Reddi and N. S. Reddi, "Pollen Production in Some Anemophilous Angiosperms," Grana, Vol. 25, No. 1, 1986, pp. 55-61. doi:10.1080/00173138609429933

[13] S. Mondal, K. N. Bhattacharya and S. Mandal, "Floral Biology, Pollen Production and Dispersal in Morus indica L. and Peltophorum inerme (Roxb.) Llanos," Journal of Palynology, Vol. 28, 1992, pp. 137-142.

[14] A. Bhattacharya, S. Mondal and S. Mondal, "Anthesis, Pollen Production and Release of Some Angiospermic Plant Taxa," Journal of Environment and Ecology, Vol. 15, No. 2, 1997, pp. 283 -287.

[15] J. Vijayakumari and G. Vilasini, "Pollen Production in Certain Medicinally Important Species of the Genus Solanum," Journal of Palynology, Vol. 41, 2005, pp. 153160.

[16] M. R. Torno, A. H. Rodriguez, I. S. Palacios and F. G. Mpez, "Pollen Production in Anemophilous Trees," Grana, Vol. 35, No. 1, 1996, pp. 38-46.

[17] P. K. K. Nair and K. Rastogi, "Pollen Production in Some Allergenic Plants," Current Science, Vol. 32, 1963, pp. 566-567.

[18] S. Mondal and S. Chanda, "Aeroallergens of West Bengal in the Context of Environmental Pollution and Respiratory Allergy," Biological Memories, Vol. 6, 1981, pp. 161.

[19] R. P. Wodehouse, "Pollen grains," McGraw-Hill Book Company, New York, 1935.

[20] R. F. Daubenmire, "Plants and Environment: A Textbook of Plant Autoecology," New York, 1947.

[21] F. Pohl, "Die Pollenerzeugung der Windblu tler. (in German.)," Beih Botanical Centra, Vol. 56, 1937, pp. 365370.

[22] M. S. Agnihotri and B. P. Singh, "Pollen Production and Allergenic Significance of Some Grasses around Lucknow," Journal of Palynology, Vol. 11, 1975, pp. 151-154.

[23] I. J. Smart, W. G. Tuddenham and R. B. Knox, "Aerobiology of Grass Pollen in the City Atmosphere of Melbourne: Effects of Weather Parameters and Pollen Sources," Australian Journal of Botany, Vol. 27, No. 3, 1972, pp. 333-342. doi:10.1071/BT9790333

[24] A. J. Bai and C. S. Reddi, "Pollen Productivity and Pollen Incidence in Some Potentially Allergenic Plants of Visakhapatnam," Advances in Pollen and Spore Research, Vol. 5, No. 7, 1980, pp. 217-224

[25] S. M. Beri and S. C. Anand, "Factors Affecting Pollen Shedding Capacity in Wheat," Euphytica, Vol. 20, No. 2, 1971, pp. 327-332. doi:10.1007/BF00056096

[26] E. A. Cahn, "Study of Fertility in Some Common Varieties of Wheat with Respect to Anther Length and Amount of Pollen in Parents and Offspring," Journal of American Agronomical Society, Vol. 17, No. 10, 1925, pp. 591-595.

[27] B. S. Trivedi and H. A.Verma, "A Study of Pollen Production and Stainability in Cassia tora L. and Arachis hypogeae L.," Journal of Palynology, Vol. 11, 1975, pp. 139-142.

[28] S. R. Rangaswami and V. S. Raman, "Pollen Production 
in Diploids and Autotetraploids of Rice (oryza sativa L)," Pollen and Spores, Vol. 15, No. 2, 1973, pp. 189-193

[29] M. Sahney and S. Chaurasia, "Pollen Production in Some Allergenic Plant Taxa of Allahabad," Indian Journal of Aerobiology, Vol. 21, No. 2, 2008, pp. 69-72.

[30] J. M. Pettit and C. B. Beck, "Seed from the Upper Devonian," Science, Vol. 156, No. 3783, 1967, pp. 1727-1729. doi:10.1126/science. 156.3783 .1727

[31] A. K. Mondal and S. Mandal, "Biochemical and Clinical Studies of Ailanthus Excels Roxb. Pollen with Reference to Its Dispersal," Bangladesh Journal of Botany, Vol. 26, 1997, pp. 115-120.

[32] R. R. Haynes, "Reproductive Biology of Selected Aquatic Plants," Annals of the Missouri Botanical Garden, Vol. 75, No. 3, 1988, pp. 805-810. doi:10.2307/2399368

[33] M. Proctor, P. Yeo and A. Lack, "The Natural History of Pollination," Harper Collins, London, 1996.

[34] J. D. Ackerman, "Abiotic Pollen and Pollination: Ecological, Functional, and Evolutionary Perspectives," Plant Systematics and Evolution, Vol. 222, No. 1, 2000, pp. 167-185.

[35] C. D. K. Cook, "Wind Pollination in Aquatic Angiosperms," Annals of the Missouri Botanical Garden, Vol. 75, No. 3, 1988, pp. 768-777. doi:10.2307/2399365

[36] C. D. Sculthorpe, "The Biology of Aquatic Vascular Plants," Edward Arnold Publication Ltd., London, 1967.

[37] P. K. K. Nair and S. K. Kapoor, "Pollen Production in Some Vegetable Crops," Geobios, Vol. 1, 1974, pp. 7173.

[38] S. Mondal and S. K. Roy, "Pollen Production in Weeds Associated with Some Rice Cultivars in Burdwan District West-Bengal India," Geophytology, Vol. 14, 1984, pp.
74-81.

[39] S. Mandal and R. Yonzone, "Pollen Production in Saifraxga ciliate," Environment and Ecology, Vol. 5, No. 2, 1986, pp. 386-387.

[40] S. Mandal and R. Yonzone, "Pollen Production in Amaryllis reginae L.," Mendel, Vol. 3, No. 3, 1987, pp. 192193.

[41] Y. O. Kho and J. Baer, "The Effect of Temperature on Pollen Production in Carnations," Euphytica, Vol. 22, No. 1, 1973, pp. 467-470. doi:10.1007/BF00021553

[42] L. R. Joppa, F. H. Macneal and M. A. Berg, "Pollen Production and Pollen Shedding of Hard Red Spring (Triticum aestivum L. em. Thell.) and Durum (T. durum Desf.) Wheat's," Crop Science, Vol. 8, No. 4, 1968, pp. 487-490. doi:10.2135/cropsci1968.0011183X000800040028x

[43] C. A. Rogers, "Application of Aeropalynological Principles in Paleoecology," Review of Palaeobotany and Palynology, Vol. 79, No. 1-2, 1993, pp. 133-140. doi:10.1016/0034-6667(93)90043-T

[44] E. Adams, W. E. Perkins and J. R. Estes, "Pollination Systems in Paspalum dilatatum Poir. (Poaceae): An Example of Insect Pollination in a Temperate Grass," American Journal of Botany, Vol. 68, No. 3, 1981, pp. 389-394. doi: $10.2307 / 2442775$

[45] T. D. Allisson, "Pollen Production and Plant Density Affect Pollination and Seed Production in Taxus canadiensis," Ecology, Vol. 7, No. 2, 1990, pp. 516-522. doi:10.2307/1940305

[46] D. Bhunia and A. K. Mondal, "Studies on Production, Morphology and Free Amino Acids of Pollen of Four Members in the Genus Nymphaea L. (Nymphaeaceae)," International Journal on Science and Nature, Vol. 3, No. 3, 2012, pp. 705-718. 